\title{
THE ROLE OF "SPIRITUALITY" AND "ETHICS" CATEGORY IN THE DEVELOPMENT OF THE UZBEK LANGUAGE
}

\author{
Shohsanam Sharifboyevna Bobojonova \\ Lecturer, Shahrisabz branch of TSPU named after Nizami
}

\section{ABSTRACT}

This article reflects the role of spirituality and morality in the spiritual development of young people. The role and importance of national spirituality in the life and development of society is widely covered.

KEYWORDS: - Morality, education, spirituality, duty, value, consciousness, behavior, pride, ideology, nationality, independence.

\section{INTRODUCTION}

The radical changes that have taken place in social life since independence have been reflected in the field of linguistics, as well as in all areas of science. A new democratic society based on high national and universal spiritual values is being built in our republic. The radical sociopolitical, economic, legal and spiritual reforms that are taking place serve the interests of man and his interests.

Man's humanity is determined, first of all, by his spiritual maturity and purity. The concept of moral education is a multifaceted and broad concept. A spiritually mature person cares about the well-being of all his relatives: parents and children, relatives, family members, neighbors, neighborhoods, villagers and the whole country. the people around him strive to be the person they need him to be, just as he needs them to be; he considers it his human duty to please his manners and character. The role and importance of national spirituality in the life and development of society is determined by the fact that it is the basis of national ideology. National spirituality and national ideology will become a powerful and influential factor in social development, educating the people in the spirit of national pride, patriotism and humanity. Thanks to national spirituality and national ideology, socio-historical practice achieves a clear goal, the development of national and universal values and their implementation in life. National spirituality can become a powerful factor of social development only when it expresses the integral unity of national and universal values. The role and status of national spirituality in the development and implementation of the national development model is related to the same thing.

\section{THE MAIN FINDINGS AND RESULTS}

Our goal is to ensure the close unity of national spirituality with both national independence and 
CURRENT RESEARCH JOURNAL OF PHILOLOGICAL SCIENCES 2(6): 17-20,

May 2021 DOI: https://doi.org/10.37547/philological-crjps-02-06-04

ISSN 2767-3758

(C)2021 Master Journals

\section{Crossref do) 8 Google}

Accepted05thJune, 2021 \& Published 10 thJune, 2021

national ideology, the relationship between them, as well as the understanding of national identity, all-round social development with morality and spirituality in general, and integration into modern world civilization. It is necessary to strengthen the research on morality, behavior, spiritual education in order to show the integral connection with the whole spiritual life of the developing Republic of Uzbekistan, to deepen the consciousness and movement of the people. "In the context of globalization, the task is to preserve the purity of our national language, increase its vocabulary, create Uzbek alternatives to modern terms in various fields, and ensure their uniform application."

The most important condition for accelerating the building of a humane, democratic society in our country is to strengthen its spiritual and moral foundations. One of the first conditions is to constantly research this issue, to strengthen the spiritual and moral foundations of the new society, not to stifle its spiritual and moral development. Therefore, strengthening the intellectual and moral potential is a priority of the development of Uzbekistan, as noted by the First President of the Republic IAKarimov. , to understand the national identity, to live in a free and free society, to fight selflessly for our independent state to take its rightful place in the world community".

National independence is based on the spiritual strength of the individual and the enormous creative potential for the development of society. An important subjective factor in strengthening it is the morality, conscientiousness, responsibility, diligence, honesty, harmony of society and self-interest, patriotism, in short, the overall moral qualities. In particular, in the field of linguistics, these include the preservation and enrichment of our native language, the expansion of its use in the field of information and communication, increasing the effectiveness of its practical use. The character of a nation can be easily learned from its morals, customs, traditions, behavior, language. Enlightener Abdullah Avloni did not say in vain that the loss of the national language is the loss of the spirit of the nation. For this reason, a rational approach to our national language is to use all its potential.

At a time when a new democratic society based on high national and universal spiritual values is being built in our country, it is important to inculcate the moral system and moral qualities in the minds of each generation in accordance with modern requirements. The ongoing spiritual reforms serve the people and their interests. Any moral, political, or legal education is aimed at defending, propagating, and developing a particular idea. The concept of morality is not a new concept for the Uzbek national social thinking, but its linguocognitive form in the Uzbek linguistic consciousness has a new color. There is no reflection of negative values in morality and its related concepts (exactly morality), so it has always lived in the minds of people as a national value and concept. Indeed, there is a nationwide need to strengthen independence and maintain peace in the country, to ensure the stability and development of the family, and therefore the objective social and linguistic value of the concept of moral units is growing.

This is the basis of the different descriptions of moral needs in world ethics, as well as in the diversity of causes and conditions that determine a person's spiritual world and behavior. Representatives of "popular culture" who do not recognize the moral norms and foundations of society, ignore human morality, its propensity for moral interests and needs, and lead to such negative consequences.

One of the main reasons why human beings live as a family and a society is because of their moral relationship with each other. Moral culture and 
CURRENT RESEARCH JOURNAL OF PHILOLOGICAL SCIENCES 2(6): 17-20,

May 2021 DOI: https://doi.org/10.37547/philological-crjps-02-06-04

ISSN 2767-3758

(C)2021 Master Journals

Crossref dof 81 Google

Accepted05thJune, $2021 \&$ Published 10thJune, 2021

attitudes are the foundation, the essence, and the "invisible chain" of human existence.

"Morality is, in fact, the core of spirituality. Human morality is not just about greetings and kindness, morality is, first and foremost, a sense of fairness and justice, faith and honesty." Because morality is not an "immutable" phenomenon. It changes, improves and adapts to the times. It is caused by a certain period and process. On this basis, it is natural that there should be positive and negative (morality and immorality). Philosophical and encyclopedic dictionaries have different categories of morality. It seems that linguistics has a common object of study with a number of disciplines, such as ethics, psychology, linguoculturology, ethnography, and sociolinguistics, but its specific subject is clearly different.

One of the components of moral purity is loyalty. Loyalty refers to the stability of the moral principles to which a person applies, his attitude to different people and events. Highly developed individuals do not change their views in any case, do not abandon their interlocutors, and are not in a state of hypocrisy and betrayal.

Diachronic and synchronous study of the category of "spirituality" allows to reveal their gradual development and formation, as well as their systemic state. It is up to us to describe the synchronous system state of the category. In defining the essence of the concept of "spirituality" and its components, we rely on the popular interpretations in the "National Encyclopedia of Uzbekistan".

"The word "morality" is derived from the Arabic word and is a plural form of the word "behavior", which means a set of behavioral and mental characteristics of a person, his actions, his nature. If we take morality as a general concept and express it in the form of a circle, the smallest part of the circle is manners, the larger part is behavior, and the most comprehensive part is morality.

Today's rapid globalization exacerbates the problem of spirituality and morality, and imposes a great responsibility on linguistics, along with other relevant disciplines. This strongly requires the formation of a separate field of study of language and spirituality linguistics.

\section{Conclusion}

This event offers an opportunity for a national approach to the Uzbek language. Any moral, political, legal education is aimed at protecting, promoting and developing our national idea. For this reason, the focus of our research is on the general semantic units of the lexical-semantic category "Spirituality" "Morality" and their lexical-semantic, genetic, structural, cognitive features.

Nowadays, as the science of linguistics rises to the level of scientific knowledge, new directions of its interaction with other disciplines are emerging. In particular, his study of philosophy broadened his horizons.

\section{ReFERENCES}

1. Jumakhojayev $\mathrm{N}$. The symbol of high spirituality // Xalq so'zi. November 5, 1997.

2. Imomnazarov M. Stages of development of our national spirituality. $\mathrm{T}$.: Manaviyat, 1996.

3. Imomnazarov M., Eshmuhamedova M. Fundamentals of our national spirituality. Tashkent: Islamic University, 2000. 
CURRENT RESEARCH JOURNAL OF PHILOLOGICAL SCIENCES 2(6): 17-20,

May 2021 DOI: https://doi.org/10.37547/philological-crjps-02-06-04

ISSN 2767-3758

(C)2021 Master Journals

Crossref doi 8 Google

Accepted05thJune, 2021 \& Published 10 ${ }^{\text {th }}$ June, 2021

4. Kamilov N. Sufism or perfect human morality: Monograph. - Tashkent: Writer, 1996.

5. Kuronov D. Introduction to literary criticism.

- Tashkent .: Akadem Publishing House, 2014. 